\title{
CHARACTERISTICS OF HONEY BEE (APIS MELLIFERA CARNICA, POLLMAN 1879) QUEENS REARED IN SLOVENIAN COMMERCIAL BREEDING STATIONS
}

\author{
Aleš Gregorc* \\ Maja I. Smodiš Škerl \\ Agricultural institute of Slovenia, Hacquetova ulica 17, 1000 Ljubljana, Slovenia \\ *corresponding author: Ales.Gregorc@kis.si \\ Received 10 April 2014; accepted 14 May 2015
}

Abstract

In this three-year-trial study, we examined the quality of mated queens based on morphological and physiology traits. At each location, sister queen bees were reared each year from one Apis mellifera carnica breeder queen. Queens were also reared and mated in different locations. Altogether, we sampled and analysed 324 queens from 27 apiaries in 2006, 288 queens from 24 apiaries in 2008, and 276 queens from 23 apiaries in 2010. Nine queens from each apiary were sampled and dissected for morphological analyses and Nosema ceranae ( $N$. ceranae) spores, if present, were quantified. Three queens from each apiary were prepared and tested for four viruses: acute bee paralysis virus (ABPV), black queen cell virus (BQCV), deformed wing virus (DWV), and sacbrood virus (SBV). The highest average queen weight of $209.49 \pm 9.82 \mathrm{mg}$ was detected in 2008 . The highest average ovary weight of $78.67 \pm 11.86 \mathrm{mg}$ was detected in 2010 , and the highest number of ovarioles was $161.59 \pm 8.70$ in 2006 . The average number of spermatozoa in queens ranged from $3.30 \times 10^{6}$ in 2006 to $5.23 \times 10^{6}$ in 2010. Nosema ceranae spores were found in queens sampled in 2008 and 2010 . Viruses were discovered sporadically during the queen testing periods from 2006 - 2010. This study importantly demonstrates that queens from rearing stations require regular evaluation for morphological and physiological changes as well as for infection from harmful pathogens. These results could also be used in establishing relevant commercial standards for rearing quality queens.

Keywords: bee virus, Nosema spp., ovariole, ovary, queen rearing, spermatheca.

\section{INTRODUCTION}

The Carniolan honeybee bee, Apis mellifera carnica Pollman 1879, is an indigenous subspecies and has been preserved in all the five geographic areas of Slovenia: Prekmurje, Štajerska, Gorenjska, Dolenjska, and the Central Region. Queen producers annually test the performance of selected colonies for queen evaluation and for further breeding. The aims of queen breeding in Slovenia are to both preserve native wildtype strains and to maintain desirable honeybee traits. However, various environmental factors can affect the quality of queen bees; for example, the rearing season and weather can alter the queens' development rate (Mahbobi et al., 2012). Therefore, evaluating morphological, behavioural, and reproductive traits of male and female bees in response to the climate within apiaries, is also important when selecting for queens. Morpho- logical traits such as body size and a bee's reproductive performance are often linked and subject to environmental factors (Reiss, 1989). If the bee is a queen, any change in body weight can irrevocably alter her egg laying capacity (Harbo, 1986). Heavier queens have more ovarioles and larger spermathecae that are capable of holding more sperm (Woyke, 1971; Szabo, 1973; Eid et al., 1980). Even large queens may lose reproductive fitness when afflicted with pathogens and parasites. The microsporidian parasite, Nosema apis, for instance, can damage ovarian tissue. This parasite can also prevent eggs from hatching, it may halt oviposition, and it may even render a weakened queen susceptible to supersedure or death (Hassanein, 1951). At the colony level, the influence of queen replacement caused by Nosema infection appears to primarily affect nurse bees and therefore worker production in afflicted colonies could be seriously 
curtailed (Botías et al., 2013). For these reasons, beekeepers claim that mated queens purchased from registered queen breeders were small and of low quality because of their low fecundity, poor survival, and weak colonies. Queen quality can be assessed using a variety of fitness-related criteria such as live weight, ovariole number, spermathecae size, and mating success (number of spermatozoa in the spermatheca) (Zhdanova, 1967; Woyke, 1971; Rhodes et al., 2004).

The aim of this study is to assess queen quality based on such queen reproductive traits as live weight, spermathecal volume, number of spermatozoa, and number of ovarioles. Because queen reproduction can be influenced by diseases, we also examined queens for infection by Nosema spores as well as for infection by four viruses. This is the first time that queen quality traits have been evaluated by Slovenian queen breeders. We anticipate that these results will help improve the standards for rearing high quality queens in Slovenia and perhaps in neighbouring countries also.

\section{MATERIAL AND METHODS}

Queen bees originated from five different geographic regions of Slovenia. All of the regions have a continental climate. These regions are: Prekmurje, Štajerska, Gorenjska, Dolenjska, and the Central Region. In total, 888 queens were evaluated every two years from apiaries in all the five regions: 324 were sampled from 27 queen rearing apiaries in 2006, another 288 queens were sampled from 24 apiaries in 2008, and in 2010, 276 additional queens were sampled from 23 apiaries. Procedures for evaluating queens in 2006 and 2008 followed those described by Hatjina et al. (2014). Twelve queens from each apiary were sampled during the same time period; between June 16 and June 20 of each sampling year, and from the same selected queen mother colony. These queens were allowed to freely mate with the drones. After insemination, all the queens were kept in mating nuclei for approximately 20 days to allow for egg laying until the appearance of larvae. Nine of the 12 queens sampled from each queen rearing apiary were dissected under a stereomicroscope and prepared for further morphological analyses (see below). The remaining three queens from each 12-queen sample were prepared for detection of the following viruses: acute bee paralysis virus (ABPV), black queen cell virus (BQCV), deformed wing virus (DWV), and sacbrood virus (SBV).

\section{Morphological analyses: weight, spermatheca volume, number of spermatozoa, number of ovarioles}

One day after sampling the queens from the mating nuclei, the queens were immediately brought to the laboratory. The queens were weighed and dissected in the laboratory. The midgut was removed from each queen and placed separately in a microtube and kept at $-20^{\circ} \mathrm{C}$ for further Nosema analyses. A photograph of each spermatheca was taken using a stereomicroscope and the volume was calculated by measuring the spermatheca diameter using the computer program AxioVision. The spermatheca outer membrane was then gently perforated to release the seminal fluid with spermatozoa. The seminal fluid was then suspended in $0.5 \mathrm{~mL}$ Hayes solution in $4.5 \mathrm{~mL}$ of distilled water (Koeniger et al., 2005). Bürker's haemocytometer was used for spermatozoa counting in 80 fields, under $400 \mathrm{x}$ magnification using phase contrast microscopy.

The ovaries from each queen were weighed using a microbalance. Next, the ovaries were fixed for $24 \mathrm{~h}$ in a $10 \%$ neutral buffered formalin solution and then dehydrated in solutions of ascending concentrations of alcohol and xylene. Finally, the ovaries were embedded in wax as described by Gregorc and Bowen (1999). Slide preparations of cross sections from the central ovary portion were stained using Mayer's haematoxylin and Eosin, and mounted permanently with a Faramount mounting medium (Dako Inc.). Stained tissue sections of one ovary from each queen were randomly selected and examined using a Zeiss stereomicroscope; a digital photo camera was used to take pictures. Only one ovary from each queen was examined because left and right ovaries have comparable numbers of ovarioles (Rhodes and Somerville, 2003). Ovarioles in ten tissue sections from each ovary were counted under 200 x magnification using Zeiss stereomicroscope. The number of ovarioles was averaged for each sampling year: 2006, 2008, and 2010.

\section{Nosema spp. spores and molecular analyses for viruses}

The sampled queens' midguts were macerated in $1 \mathrm{~mL}$ PBS (Phosphate buffered saline) and a drop of suspension was examined under $400 \mathrm{x}$ magnification and Nosema spp. identified (Cantwell, 1970). Spores were counted using the Bürker haemocytometer. Molecular determination and differentiation between $N$. apis and $N$. ceranae spores were conducted using $100 \mu \mathrm{L}$ of the spore suspension solutions. The sampled queens' midguts were 
pooled from the same apiaries. DNA isolation was conducted as described by De Graaf et al. (1993). DNA extraction was performed using the High Pure PCR Template Preparation Kit (Roche Diagnostic), according to the manufacturer's instructions. Finally, isolated DNA (200 $\mu$ L) was stored at $-20^{\circ} \mathrm{C}$ until a further Duplex PCR technique was employed according to the OIE Terrestrial Manual (2008). Selected primers were used. PCR was performed using a Mastercycler (Biometra) in $25 \mu \mathrm{L}$ volumes containing $\mathrm{Mg}^{2+}$, each of primer specific to viruses tested in the experiment, BSA, Triton, template DNA, and Expand High Fidelity PCR System (Roche Diagnostic). The PCR activation step was followed by denaturation. For each pair of primers, annealing and extension was conducted according to the method described by Higes et al. (2006). Amplified PCR products were electrophoresed through 2\% agarose TAE (Tris-acetate-ethylene diamine tetraacetic acid) gel in a standard TAE buffer, stained in ethidium bromide, and illuminated with UV light.

For virus analyses each queen was separately macerated in a microtube containing PBS. Viral RNA was isolated using a QIAamp Viral RNA Mini Kit (Qiagen, Germany) according to the instructions. Altogether, 232 queens were examined (81 queens from the year 2006, 72 from 2008, and 69 queens from 2010) for the presence of ABPV, BQCV, DWV, and SBV, as cited by Gregorc and Bakony (2012).

Viral RNA was reverse transcribed and amplified by a continuous RT-PCR method with the One Step RT-PCR kit (QIAGEN, Germany), according to the manufacturer's instructions. The specific primer pairs for the four viruses were designed based on the partial or complete sequences of the virus genomes deposited in the GenBank database (Berényi et al., 2006).

Amplifications were performed in a GeneAmp PCR System 2400 thermal cycler (Perkin-Elmer). The reverse transcription was followed by a denaturation and polymerase activation step and by 40 cycles of PCR. The PCR products were electrophoresed in a $1.2 \%$ Tris-acetate-EDTA-agarose gel and stained with ethidium bromide as described by Berényi et al. (2006). Bands were photographed under UV light (Biometra). Fragment sizes were determined with reference to a 100-bp ladder (Рromega).

\section{Statistics}

Mean queen weight, ovariole number, and number of spermatozoa per spermatheca were compared among queens, rearing apiaries, and sampling years, using one-way analysis of variance (ANOVA). Pearson rank correlations (Graph Pad Prism 3.0) measured the strength of the relationships $(\alpha=0.05)$ between queen weight, ovary weight, and ovariole number. The Scheffe test was also used to compare the number of spermatozoa versus spermathecae volume. The data were analysed with the aid of the Statgraphic Plus program (1996).

\section{RESULTS}

\section{Weight of queens and ovaries, and number of ovarioles}

Average queen and ovary weights and the differences between years are shown in Table 1. The highest queen weights were detected in 2008. The highest ovary weights were detected in 2010. The ratio between queen weight and ovary weight in all the three years was 2.98, 2.86, and 2.56, respectively. The highest proportion of an individual queen's ovary weight in comparison to the total queen body weight was $44.42 \%$ and the lowest proportion was $26.63 \%$. The highest and the lowest ratios of ovary weight to queen weight occurred in 2006 and 2010; 38.97\% and 33.49\%, respectively. We found that queen weight correlated with ovary weight $(r=0.5243, p<0.001)$ and that ovary weight weakly correlated with ovariole number in all tested queens ( $r=0.2641, p<0.05$ ). No correlation occurred between queen weight and the number of ovarioles ( $r=0.0384$ ). Moreover, there was no correlation between queen weight and the number of sperm in spermathecae ( $r=0.0568, p>0.05)$.

Table 1.

Average weights of queens, ovaries, and number of ovarioles ( \pm standard deviation). The same letters indicate that Scheffe tests $(P<0.05)$ established that values between years were not significantly different

\begin{tabular}{cccc}
\hline Year & Queen weight $(\mathrm{mg})$ & Ovary weight $(\mathrm{mg})$ & Ovariole No. \\
\hline $\mathbf{2 0 0 6}$ & $208.40 \pm 15.31^{\mathrm{a}}$ & $69.82 \pm 11.08^{\mathrm{a}}$ & $161.59 \pm 8.70^{\mathrm{a}}$ \\
\hline $\mathbf{2 0 0 8}$ & $209.49 \pm 9.82^{\mathrm{ab}}$ & $73.05 \pm 9.82^{\mathrm{a}}$ & $149.09 \pm 7.96^{\mathrm{a}}$ \\
\hline $\mathbf{2 0 1 0}$ & $201.83 \pm 15.85^{\mathrm{c}}$ & $78.67 \pm 11.86^{\mathrm{a}}$ & $135.02 \pm 10.51^{\mathrm{a}}$ \\
\hline
\end{tabular}




\section{Number of spermatozoa}

The number of spermatozoa varied from $8.00 \times 10^{5}$ to $6.01 \times 10^{6}$ in 2006, and from $3.34 \times 10^{6}$ to $6.69 \times 10^{6}$ in 2008; the spermatheca volume varied from 0.75 to $1.09 \mathrm{~mm}^{3}$. In the three year period, the average number of spermatozoa in the spermathecae of the queens originating from breeders are shown in Figure 1. The average spermathecal volume was 0.89 ( \pm 0.10 ) for queens tested in 2008 and 0.87 ( \pm 0.10 ) for queens tested in 2010 with no size difference detected between these two years $(P>0.05)$.

\section{Presence of Nosema spp. spores}

Nosema ceranae spores were found in 3.4\% queens in 2008 and in $1.8 \%$ queens in 2010 (Tab. 2). After performing molecular tests, all Nosema positive samples were confirmed as $N$. ceranae.

\section{Viral RNA detection}

The incidence of all the tested viruses, in queens from rearing apiaries, is shown in Table 3. The highest percentage queens infected with virus was detected for DWV in 2008 (65.28\%), the second for BQCV in 2010. The incidence of ABPV and DWV was uneven in the considered period. However,

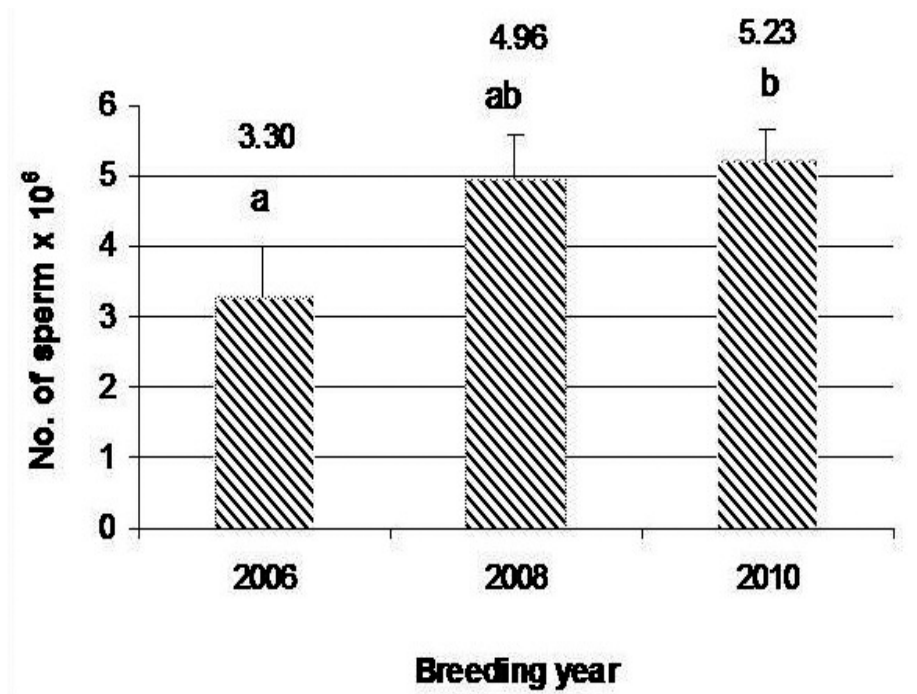

Fig. 1. Mean numbers of spermatozoa $\times 10^{6}$ in the three year period: 2006, 2008, and 2010. Bars indicate standard deviation. The same letters indicate that Scheffe tests $(P<0.05)$ established that values between years were not significantly different.

Table 2.

Number of queens examined and found positive for the presence of $N$. ceranae spores in 2006, 2008, and 2010

\begin{tabular}{cccc}
\hline Year & 2006 & 2008 & 2010 \\
\hline Number of examined queens & $\mathrm{n}=324$ & $\mathrm{n}=288$ & $\mathrm{n}=276$ \\
\hline Number of examined apiaries & $\mathrm{N}=27$ & $\mathrm{~N}=24$ & $\mathrm{~N}=23$ \\
\hline Number of positive queens & 0 & 10 & 5 \\
\hline
\end{tabular}

Table 3.

The rate of queens infected with four bee viruses (ABPV - acute bee paralysis virus; BQCV black queen cell virus; SBV - sacbrood virus; DWV - deformed wing virus). In 2006, analyses were performed on 81 queens sampled from 27 rearing apiaries. In 2008, analyses were performed on 72 queens from 24 apiaries, and in 2010, on 69 queens sampled from 23 rearing apiaries

\begin{tabular}{ccccc} 
& \multicolumn{4}{c}{ Rate of infected queens (\%) } \\
\hline Year & ABPV & DWV & BQCV & SBV \\
\hline 2006 & 12.50 & 8.75 & 0.00 & 1.25 \\
\hline 2008 & 4.17 & 65.28 & 23.61 & 8.33 \\
\hline 2010 & 21.74 & 4.35 & 34.78 & 8.70 \\
\hline
\end{tabular}


the proportion of queens infected with BQCV and SBV, showed a growing trend: the incidence of BQCV increased from zero in 2006 to $34.78 \%$ in 2010 , and SBV increased from an initial infection of $1.25 \%$ in 2006 to $8.70 \%$ in 2010.

\section{DISCUSSION}

The body weight of queens is influenced by the age at which the young larva is grafted, by genetic factors, and to a large extent, by external rearing conditions such as pasture abundance and weather conditions (Woyke, 1971; Weiss, 1974; Meyer, 1975; Skowronek et al., 2004; Büchler et al., 2013). It seems that a low frequency of Nosema and virus infections exert little influence on the general health and body weight of queen honey bees (Chen et al., 2005; Roy and Kryger, 2012). However, queen rearing methods vary between apiaries, change from year to year, and could exert far greater influence over morphologically-based fitness traits of queen bees. For instance, the number of ovarioles in a queen's ovaries correlates with her larval age at the time of grafting (Woyke, 1971; Ruttner, 1983). Queens reared from one-day-old larvae have, on average, 154 ovarioles, queens reared from two-day old larvae have 146 ovarioles, and queens reared from three-day old larvae have 136 ovarioles. A quality queen should have about 150 ovarioles (Ruttner, 1983; Carreck et. al, 2013). In A. m. carnica, the number of ovarioles range between 145-160 (Hatjina et al., 2014), the level of a quality queen. In our survey, the average number of ovarioles in queens exceeded the recommended number for a quality queen, but decreased continuously from 2006 to 2010, starting with the highest number of 161 in 2006, to the lowest number of ovarioles of 135 in 2010. However, the average number of ovarioles was 149, indicating overall good queen quality from Slovenian apiaries. Queen quality, besides her own reproductive potential, is also determined by mating success. A fully-mated queen typically stores from 5 million to 7 million sperm in her spermatheca (Woyke, 1962). In our three-year survey, the lowest and the highest detected average sperm counts from apiaries varied from 2.36 million sperm per queen to 6.11 million sperm with an average 4.43 million spermatozoa. Our average sperm count was comparable to sperm counts for 80 commercially produced queens in California (Tarpy et al., 2012).

Camazine et al. (1998) examined 325 queens from 13 different commercial queen breeders and they found that $19 \%$ of the queens were "poorly mated" because their spermathecae contained fewer than 3 million sperm. On average, 15\% of the tested queens from our apiaries carried fewer than 3 million sperm and $36 \%$ of the queens had more than 5 million sperm in their spermathecae. The rearing season also has an impact on the number of spermatozoa in the queen's spermathecae (Güler and Alpay, 2005; Koç and Karacaoglu, 2011). Our results show that a standard for acceptable queen quality can be established. This standard includes a queen that weighs $200 \mathrm{mg}$, contains $\sim 150$ ovarioles, and is capable of storing $4 \times 10^{6}$ or more spermatozoa. In addition, Nosema spores or any other signs of disease should not be present. Queen rearing is an important beekeeping activity that ensures the availability of quality queens. Furthermore, rearing productive queens is a priority for the beekeeping sector. The purchase and the replacement of queens in colonies is also associated with some risk of pathogen e.g. Nosema spores and virus introduction (Gregorc et al., 1991; 1992; Czekonska, 2000). The objective of breeding activities and queen marketing, is also to reduce the potential transmission of the causative agents of disease. It was found that mating can transmit viral disease; mated queens are older than virgin queens, which results in a higher probability of infection from workers or as a result of vertical virus transmission (Gauthier et al., 2011). In our previous research, we noted that DWV was found in normally-developed, laying queens despite Varroa control (Gregorc and Bakony, 2012).

The results of this survey will help queen breeders and extension specialists improve rearing technologies and queen mating conditions that are essential for certifying queens for commercial sale. Our data will hopefully contribute to a better understanding of how measurements of morphological and physiological traits can provide a standard from which to breed higher quality queens with greater mating success and reproductive fitness.

\section{CONCLUSIONS}

Based on the 888 mated honey bee queens sampled during this study, we suggest a new standard for rearing and mating quality queens in Slovenia. Queens should be Nosema-free, weigh 206 mg, have an average of 149 ovarioles, and be capable of storing $\sim 4$ million sperm, on average. Queens obtained from queen-rearing apiaries are produced for the beekeeping market and basic queen quality standards must be taken into consideration. 


\section{ACKNOWLEDGEMENTS}

We would like to thank our colleagues Marjan Kokalj(†), Vesna Lokar, and Mitja Nakrst, for their technical assistance, and Mrs. Yvonne Bernik and Blair Sampson for their English and scientific editing. This work was supported by the Slovenian Ministry of Higher Education, Science, and Technology (Research programme P4-133), the Ministry of Agriculture, Forestry, and Food research project (No. V4-1114) and 'Uredba o izvajanju Programa ukrepov na področju čebelarstva $v$ Republiki Sloveniji', and by the FP7 Project CropSustaln, grant agreement FP7 - REGPOT - CT2012-316205. The work is part of the COLOSS activities.

\section{REFERENCES}

Berényi O., Bakonyi T., Derakhshifar I., Köglberger H., Nowotny N. (2006) Occurrence of Six Honeybee Viruses in Diseased Austrian Apiaries. Applied Environmental Microbiology 72(4): 2414-2420.

Botías C., Martín-Hernández R., Barrios L., Meana A., Higes M. (2013) Nosema spp. infection and its negative effects on honey bees (Apis mellifera iberiensis) at the colony level. Veterinary Research 44: 25. DOl: 10.1 186/1297$9716-44-25$

Büchler R., Andonov S., Bienefeld K., Costa C., Hatjina F., Kezic N., Kryger P., Spivak M., Uzunov A., Wilde J. (2013) Journal of Apicultural Research 52(1): 1-29. DOl: 10.3896/IBRA.1.52.1.07

Camazine S., Cakmak I., Cramp K., Finley J., Fisher J., Frazier M., Rozo A. (1998) How healthy are commerciallyproduced US honey bee queens? American Bee Journal 138: 677-680.

Cantwell G. E. (1970) Standard methods for counting nosema spores. American Bee Journal 1 10: 222-223.

Carreck N. L., Andree M., Brent C. S., Cox-Foster D., Dade H. A., Ellis J. D. Hatjina F., VanEngelsdorp D. (2013) Standard methods for Apis mellifera anatomy and dissection. In: Dietemann V., Ellis J. D., Neumann P. (Eds.) The COLOSS BEEBOOK, Volume I: standard methods for Apis mellifera research. Journal of Apicultural Research 52(4): 1-40. DOl: 10.3896/IBRA. 1.52.4.03

Chen Y. P., Higgins J. A., Feldlaufer M. F. (2005) Quantitative real-time reverse transcription-PCR analysis of deformed wing virus infection in the honeybee (Apis mellifera L.). Applied and Environmental Microbiology 71: 436-441.

Czekońska K. (2000) The influence of Nosema apis on young honey bee queens and transmission of the disease from queens to workers. Apidologie 31(6): 701706. DOl: 10.1051/apido:2000154

De Graaf D. C., Maschelein G., Vandergeynst F., De Brabander H. F., Jacobs F. J. (1993) In vitro germination of Nosema apis (Microspora: Nosematidae) spores and its effect on their a a-trehalose/D-glucose ratio. Journal of Invertebrate Pathology 62(3): 220-225. DOI: 10.1006/ jipa.1993.1103

Eid M. A. A., Ewies M. A., Nasr M. S. (1980) The weight of the newly emerged honeybee queens as an index of its potential productivity. Bulletin of Faculty of Agriculture, University of Cairo 29: 91-111.

Gauthier L., Ravallec M., Tournaire M., Cousserans F., Bergoin M., Dainat B., de Miranda J. R. (2011) Viruses associated with ovarian degeneration in Apis mellifera $L$. queens. PLoS ONE 6(1): e16217. DOl: 10.1371/journal. pone.0016217

Gregorc A., Bakony T. (2012) Viral infections in queen bees (Apis mellifera carnica) from rearing apiaries. Acta veterinaria Brno 81: 15-19. DOl: 10.2754/ avb201281010015

Gregorc A., Bowen I. D. (1999) In situ localization of heatshock and histone proteins in honey-bee (Apis mellifera L.) larvae infected with paenibacillus larvae. Cell biology international 23: 211-218.

Gregorc A., Fijan N., Poklukar J. (1992) The effect of Apis mellifera carnica Polm worker bee source for populating mating nuclei on degree of infection by Nosema apis Zander. Apidologie 23(3): 241-244. DOl: 10.1051/ apido:19920307

Gregorc A., Poklukar J., Perko M., Babnik D. (1991) Incidence of nosema disease in queen-rearing (Apis mellifera Pollm.) apiaries in Slovenia. Zbornik Veterinarske fakultete, Univerze v Ljubljani 28(1): 19-24.

Güler A., Alpay H. (2005) Reproductive characteristics of some honeybee (Apis mellifera L.) genotypes. Journal of Animal and Veterinary Advances 4(10): 864-870. Available at: http://docsdrive.com/pdfs/medwelljournals/ javaa/2005/864-870.pdf 
Harbo J. R. (1986) Oviposition rates of instrumentally inseminated and naturally mated queen honey bees (Hymenoptera: Apidae). Annals of the Entomological Society of America 79(1): 112-115.

Hassanein M. H. (1951) Studies on the Effect of Infection with Nosema apis on the Physiology of the Queen Honey-bee. Quarterly Journal of Microscopical Science 92: 225-231. Available at: http://jcs.biologists.org/content/s3-92/18/225.full.pdf+html

Hatjina F., Bieńkowska M., Charistos L., Chlebo R., Costa C., Dražić M. M., Filipi J., Gregorc A., Ivanova E. N., Kezic N., Kopernicky J., Kryger P., Lodesani M., Lokar V., Mladenovic M., Panasiuk B., Petrov P. P., Rašić S., Smodis Skerl M. I., Vejsnæs F., Wilde J. (2014) A review of methods used in some European countries for assessing the quality of honey bee queens through their physical characters and the performance of their colonies. Journal of Apicultural Research 53(3): 337-363.

Higes M., Martín R., Meana A. (2006) Nosema ceranae, a new microsporidian parasite in honeybees in Europe. Journal of Invertebrate Pathology 92(2): 93-95. DOl: 10.1016/j.jip.2006.02.005

Koç A. U., Karacaoglu M. (2011) Effects of queen rearing period on reproductive features of Italian (Apis mellifera ligustica), Caucasian (Apis mellifera caucasica), and Aegean ecotype of Anatolian honey bee (Apis mellifera anatoliaca) queens. Turkish Journal of Veterinary and Animal Sciences 35(4): 271-276. Available at: http:// journals.tubitak.gov.tr/veterinary/issues/vet- 1 1-35-4/ vet-35-4-8-1007-375.pdf

Koeniger $G_{\text {., }}$ Koeniger N., Tingek S., Phiancharoen M. (2005) Variance in spermatozoa number among Apis dorsata drones and among Apis mellifera drones. Apidologie 36(2): 279-284. DOl: 10.1051/apido:2005009

Mahbobi A., Farshineh-Adi M., Woyke J., Abbasi S. (2012) Effects of the age of grafted larvae and the effects of supplemental feeding on some morphological characteristics of Iranian queen honey bees (Apis mellifera meda, Skorikov 1929). Journal of Apicultural Research 56(1): 93-98. DOI: 10.2478/v10289-012-0010-1

Meyer W. (1975) Jungkönigin, EWK und Insebegstelle. Allgemeine Deutsches Imkerzeitung 9: 151-152.

OIE Terrestrial Manual 2008. Available at: http://www. oie.int/fr/normes/mmanual/2008/pdf/2.02.04_NOSEMOSIS.pdf
Reiss M. J. (1989) The Allometry of Growth and Reproduction. Cambridge University Press. Cambridge, Massachusetts. 4 pp. Available at: https://ebooks.cambridge. org/pdf_viewer.jsf?cid=CB0978051 1608483A004\&re $\mathrm{f}=$ false\&pubCode=CUP\&ur|Prefix=cambridge\&productC ode $=$ cbo

Rhodes J. W., Somerville D. C. (2003) Introduction and earIy performance of queen bees - some factors affecting success. A report for the Rural Industries Research and Development Corporation. Rural Industries Research and Development Corporation. Kingston. 44 pp.

Rhodes J. W., Somerville D. C., Harden S. (2004) Queen honey bee introduction and early survival - effects of queen age at introduction. Apidologie 35(4): 383-388. DOl: 10.1051/apido:2004028

Roy M. F., Kryger P. (2012) Single assay detection of acute bee paralysis virus, Kashmir bee virus and Israeli acute paralysis virus. Journal of Apicultural Science 56: 137-146.

Ruttner F. (1983) Queen rearing. Apimondia Publishing House. Bucharest. 358 pp.

Skowronek W., Bieńkowska M., Kruk C. (2004) Changes in body weight of honeybee queens during their maturation. Journal of Apicultural Science 48(2): 61-68. Available at: http://www.jas.org.pl/jas_48_2_2004_7.pdf

Statgraphic plus (1996) Statistical graphic system. STSC Inc. Rockville.

Szabo T. I. (1973) Relationship between weight of honey-bee queens (Apis mellifera L.) at emergence and at the cassation of egg laying. American Bee Journal 113(7): 250-251.

Tarpy D. R., Keller J. J., Caren J. R., Delaney D. A. (2012) Assessing the Mating ,Health' of Commercial Honey Bee Queens. Journal of Economic Entomology 105(1): 20-25.

Weiss K. (1974) The weight of honeybee queens seen in dependence of the larva's grafting age and its food supply. Apidologie 5: 127-147.

Woyke J. (1962) Natural and artificial insemination of queen honeybees. Bee World 43: 21-25. Available at: http://jerzy_woyke.users.sggw.pl/1962_nat_artins.pdf 
Woyke J. (1971) Correlations between the age at which honey bee brood was grafted, characteristics of the resultant queens, and results of insemination. Journal of Apicultural Research 10: 45-55.
Zhdanova T. S. (1967) Influence of nest temperature on quality of queens produced artificially. In: The XXIst International Apicultural Congress Apimondia. University of Maryland - USA. 14-17 August 1967: 245-249. 